\title{
Pharmacologic Decision-making in the Treatment of Focal Epilepsy- A Critical Comparison of Antiepileptic Drugs
}

\author{
Selim R Benbadis, MD, ${ }^{1}$ Hermann Stefan, MD, ${ }^{2}$ Diego Morita, MD, ${ }^{3}$ Bassel Abou-Khalil, MD ${ }^{4}$ and R Edward Hogan, $\mathrm{MD}^{5}$ \\ 1. University of South Florida, Tampa, Florida, US; 2. University Hospital Erlangen (FAU), Erlangen, Germany; 3. Cincinnati Children's Hospital Medical Center, \\ Cincinnati, Ohio, US; 4. Vanderbilt University Medical Center, Nashville, Tennessee, US; 5. Washington University in St Louis, St Louis, Missouri, US
}

\begin{abstract}
Physicians who treat patients with epilepsy must balance many factors when selecting the appropriate treatment for an individual patient, including seizure type, concomitant antiepileptic drug (AED) therapy, age, comorbid conditions, and even insurance coverage. Optimal management of seizures is further complicated by a continuously increasing pool of AEDS. As seizure type is a main factor in AED selection, this review will provide an evidence-based guide for physicians treating focal epilepsy. This includes a summary of efficacy, safety, and tolerability data from randomized clinical trials as well as findings related to rational polypharmacy, drug-drug interactions, comorbidities, drug administration (titration, dosing, formulation), US Food and Drug Administration (FDA)-approved indications, and cost. Following the review are four case reports that provide real-life examples of clinical challenges physicians face, particularly when dealing with special populations, which highlight the decision-making process entailed when determining the best course of treatment for patients with epilepsy.
\end{abstract}

\section{Keywords}

Epilepsy, antiepileptic drug, focal seizures, treatment decisions, enzyme inducers, effectiveness, cost

\begin{abstract}
Disclosure:SelimRBenbadis,MD, hasservedasaconsultantfor Cyberonics, Eisai, Lundbeck, Sunovion, Supernus, UCBPharma;is onthe speakersbureauforCyberonics, GlaxoSmithKline, Lundbeck, Supernus, and UCB Pharma; has received grant support from Cyberonics, Lundbeck, Sepracor, Sunovion, Supernus, UCB Pharma, and Upsher-Smith Laboratories; has received royalties as an author or editor for Emedicine-Medscape-WebMD, UpToDate; and is on the Editorial Board for Emedicine-Medscape-WebMD, European Neurology, Epileptic Disorders, Epilepsy and Behavior, and the Expert Review of Neurotherapeutics. Hermann Stefan, MD, has received grant support from Deutsche Forschungsgemeinschaft (DFG-STE 380/14-1, 151); has received honoraria from Cyberonics, Desitin, Eisai, Electa, Merz, Novartis, and UCB; has received royalties as an editor of Epilepsy Part l: Basic Principles and Diagnosis: Handbook of Clinical Neurology, and Epilepsy Part II: Treatment: Handbook of Clinical Neurology (Newnes Elsevier 2012); and has served on speakers bureaus for Cyberonics, Desitin, Eisai, Electa, Novartis, andUCB.Diego Morita, MD, servesontheBoard of Directors of the EpilepsyFoundation ofGreater Cincinnatiand Columbus; hasservedasconsultantforUpsher-Smith Laboratories; has received institutional grant support from Eisai; and has received payment for development of educational presentations as CME Course Director, PeerView Press. Bassel AbouKhalil, MD, has received institutional grant support from GlaxoSmithKline, Pfizer, UCB, Upsher-Smith Laboratories, and Valeant; and has received royalties as an author of the Atlas of EEG \& Seizure Semiology (Elsevier 2005). R Edward Hogan, MD, has received institutional funding of clinical trials from Eisai and Upsher-Smith Laboratories; and has served as consultant for Upsher-Smith Laboratories.

Acknowledgment: Writing and editorial support was provided by Kristen A Andersen, PhD, of Prescott Medical Communications Group in Chicago, Illinois and was funded by Upsher-Smith Laboratories, Inc., Maple Grove, Minnesota, US.

Received: July 16, 2014 Accepted: August 7, 2014 Citation: US Neurology, 2014;10(2):ePub ahead of print DOI: 10.17925/USN.2014.10.02.2

Correspondence: Selim R Benbadis, MD, Director, University of South Florida/Tampa General Hospital Comprehensive Epilepsy Program, 2 Tampa General Circle, 6th Floor,

Tampa, Florida, US. E: sbenbadi@health.usf.edu
\end{abstract}

Support: The publication of this article was supported by Upsher-Smith Laboratories, Inc.

Epilepsy is a general term used to describe a collection of common, chronic conditions of recurrent and unpredictable seizures. While seizures in newly diagnosed patients are often controlled with a single antiepileptic drug (AED), ${ }^{1}$ the estimated $30-40 \%$ of patients who are resistant to monotherapy could benefit from a combination of two or more carefully selected AEDs. ${ }^{2,3}$ The reasons for AED treatment failures are as complex as the disease itself and likely depend, at least partly, on initial treatment decisions. ${ }^{4}$
Prior to the recent influx of nearly two dozen AEDs to the pharmacopeia, treatment choices in epilepsy were fairly straightforward, but arguably limited. Today, the decision as to which AED to administer can be a daunting task given the sheer number of AEDs available, lack of headto-head drug comparisons, and the staggering array of patient-specific variables that physicians must consider when choosing an appropriate treatment regimen. Among the many factors that can affect response to AEDS are the type of seizure, disease stage, prior and current AED 
therapy, age, concomitant medications, and comorbid conditions. Given the serious nature of epilepsy and the complexity of the drugs currently available to treat it, prescribing AEDs using only a trial-and-error approach may not be the best strategy. Thus, a more sophisticated method for treatment decisions is desirable in order to meet individual patient needs and to optimize patient outcome.

Not all AEDs are effective for both focal (partial-onset) and generalized seizures, and one of the most important factors in choosing an AED is the type of seizure and epilepsy syndrome being treated. ${ }^{5}$ While focal seizures overall are successfully managed with the recently approved AEDs, an important subset of patients remain refractory to treatment. ${ }^{5}$ Almost all of the second- and third-generation AEDs have been approved based on their efficacy and safety as adjunctive treatment for focal seizures. 6,7 Thus, most of the data available for comparative evaluations of the newer AEDS are from trials in which patients were already taking at least one AED (with or without concurrent use of vagus nerve stimulation).

This review will consider evidence that can affect treatment decisions for focal epilepsies. Generalized epilepsies and treatment decisions for generalized seizures (including absence, myoclonic, and tonic-clonic seizures, as well as Lennox-Gastaut or West syndromes) will not be discussed.

\section{What to Compare-What Matters When We Choose an Antiepileptic Drug?}

Randomized clinical trials (RCTs) are designed to assess the efficacy, tolerability, and safety of a particular drug compared with placebo within the strict confines of an a priori-defined study design. As such, results from drug trials can fail to answer common clinical questions. 8,9 While efficacy is naturally the most important factor when choosing an AED, it exists in partnership with many other factors, all of which can contribute to drug effectiveness-how a treatment works under ordinary conditions, administered by the typical practitioner to the typical patient. To guide treatment decisions, physicians need some indication as to how efficacious one AED can be compared with another (or in combination with another) while being mindful of patient- and drug-specific variables that can influence treatment success, including safety and tolerability, drug-drug interactions, dosing, and cost.

\section{Rational Polytherapy}

The explosion of a variety of new AEDs to the market in recent years has renewed interest in combination therapy for epilepsy, particularly for patients who are not adequately controlled with a single AED. Though monotherapy is considered the standard of care for patients with newly diagnosed epilepsy, treatment with two or more AEDs has been shown to be effective in patients who do not achieve adequate seizure control following sequential monotherapy. ${ }^{10}$ The term 'rational polytherapy' (or 'polypharmacy') has been used to describe the careful selection of drug combinations intended to improve overall treatment effect without added drug toxicity. ${ }^{11}$ In practice, implementing rational polytherapy can be quite challenging as evidence from prospective trials designed to identify optimal AED combinations is lacking. However, given the roughly 200 two-drug combinations and $>1,000$ three-drug combinations that are possible with currently available AEDS, prospective comparative efficacy trials are impractical and costprohibitive. ${ }^{11}$ Most of what is currently known about particular AED combinations has been derived from clinical experience or gleaned from retrospective and post hoc exploratory analyses.
The decision to add a drug to a treatment regimen rather than pursue sequential monotherapy can have several advantages, including the potential for synergistic effects. Because of the successful combination of drugs with differing mechanisms of action (MOA) for a number of other diseases (e.g. Alzheimer's disease, HIV, diabetes), a similar approach for epilepsy seems logical, and one would expect greater likelihood of synergistic effects when combining AEDs with different MOAs. While clinical and preclinical evidence suggests that drug effectiveness can be increased by combining a sodium-channel blocking AED with a drug that enhances GABAergic neurotransmission, the only AED combination that has shown a synergistic effect to date is lamotrigine (LTG) combined with valproate (VPA).,2,12,13 Moreover, the efficacy of two or more sodium-channel blocking AEDs combined may not be more efficacious than each drug alone. ${ }^{2}$ Complicating an MOA-based treatment strategy is the fact that most AEDs do not have a single known MOA, with several AEDS having affinity for several molecular targets (e.g., VPA, topiramate [TPM], and gabapentin [GBP]). Such 'multi-target' AEDs may, however, be advantageous for patients suffering from several types of seizures with multiple underlying disease mechanisms, but their use in specific AED combinations for focal seizures is difficult to determine given the limited data.

Although synergistic effects are difficult to ascertain, combinations of AEDS with differing MOAs have shown positive effects in patients with focal seizures. In a post hoc exploratory analysis, efficacy of lacosamide (LCM, a sodium-channel blocking AED) in combination with either non sodiumchannel blocking AEDS (SCB-) or sodium-channel blocking AEDS (SCB+) was evaluated. ${ }^{14}$ Sodium-channel blocking AEDs were defined as carbamazepine (CBZ), LTG, oxcarbazepine (OXC), or phenytoin (PHT). At the highest approved dose of $L C M$, the median percent reduction from baseline in seizure frequency was numerically higher in the SCB- group versus the SCB+ group ( $63 \%$ versus $39 \%$ ), although both groups did demonstrate significant improvement versus placebo. ${ }^{14}$ In a retrospective examination of AED combinations used most frequently, superior efficacy (seizure freedom for $\geq 12$ months, measured head-to-head) was found for LTG combined with VPA and for CBZ combined with TPM over other AED combinations or monotherapy: ${ }^{15}$

- $\quad \mathrm{LTG}+\mathrm{VPA}>\mathrm{VPA}$ or LTG monotherapy;

- $\quad \mathrm{LTG}+\mathrm{VPA}>\mathrm{CBZ}+\mathrm{VPA}$; VPA+GBP; $\mathrm{CBZ}+\mathrm{VPA}+\mathrm{PHT}$; and

- $\quad \mathrm{CBZ}+\mathrm{TPM}>\mathrm{CBZ}$ monotherapy.

Patients in this study were developmentally disabled and the types of seizures were heterogeneous (including Lennox-Gastaut syndrome and primary generalized seizures); therefore, though compelling, these results are difficult to extrapolate to the adjunctive treatment of patients with focal seizures.

Lastly, a recent study corroborates that combining AEDs with different MOAs results in overall better effectiveness. ${ }^{16}$

Until evidence-based guidelines are available to recommend specific AED combinations, physicians must carefully consider the available data for the many factors that are discussed below when determining an appropriate adjunctive AED for patients with focal epilepsy.

\section{Efficacy}

\section{Seizure Reduction}

Primary efficacy endpoints in RCTs measure seizure reduction from baseline by determining the $50 \%$ responder rate (the proportion of patients 
Table 1: Newer Antiepileptic Drugs for Adjunctive Treatment of Patients With Focal Epilepsy

\begin{tabular}{|c|c|c|c|c|c|c|c|c|c|c|c|c|c|}
\hline \multirow[t]{2}{*}{$\begin{array}{l}\text { Drug/Brand Name } \\
\text { (Approval) }\end{array}$} & \multirow[t]{2}{*}{$\begin{array}{l}\text { Maximum } \\
\text { Approved Dose }\end{array}$} & \multicolumn{4}{|c|}{$\begin{array}{l}\text { Seizure Reduction From Baseline for } \\
\text { Maximum Approved Dose, median \% }\end{array}$} & \multicolumn{4}{|c|}{$\begin{array}{l}\text { Responder Rate for Maximum } \\
\text { Approved Dose, }{ }^{\text {a }} \text { patients }\end{array}$} & \multicolumn{4}{|c|}{$\begin{array}{l}\text { Seizure Freedom for Maximum } \\
\text { Approved Dose, }{ }^{\text {, } \% \text { patients }}\end{array}$} \\
\hline & & Drug & PBO & Diff & Ref & Drug & PBO & Diff & Ref & Drug & PBO & Diff & Ref \\
\hline $\begin{array}{l}\text { Eslicarbazepine/ } \\
\text { Aptiom }^{\circledast}(2013)\end{array}$ & $1,200 \mathrm{mg} /$ day (qd) & $35^{c, d}$ & $16^{c, d}$ & 19 & 17 & $41^{\mathrm{d}, \mathrm{e}}$ & $22^{\mathrm{d}, \mathrm{e}}$ & 19 & 17 & $4.2^{\mathrm{c}, \mathrm{d}}$ & $1.2^{\mathrm{c}, \mathrm{d}}$ & 3 & $18-20$ \\
\hline $\begin{array}{l}\text { Gabapentin/ } \\
\text { Neurontin® (1993) }\end{array}$ & $\begin{array}{l}1,800 \mathrm{mg} / \text { day } \\
\text { (600 mg tid) }\end{array}$ & 32 & 6 & 26 & 21 & 26 & 8 & 18 & 22 & & NR & & \\
\hline $\begin{array}{l}\text { Lacosamide/ } \\
\text { Vimpat }{ }^{\circledR}(2008)\end{array}$ & $\begin{array}{l}400 \mathrm{mg} / \mathrm{day} \\
\text { (200 mg bid) }\end{array}$ & $37^{c, d}$ & $18^{c, d}$ & 19 & 23 & $40^{d}$ & $23^{d}$ & 17 & 23 & $3.3^{c, d}$ & $0.9^{c, d}$ & 2.4 & $24-26$ \\
\hline $\begin{array}{l}\text { Lamotrigine/ } \\
\text { Lamictal}^{\circledast}(1994)\end{array}$ & $\begin{array}{l}500 \mathrm{mg} / \text { day } \\
\text { (in } 2 \text { divided doses) }\end{array}$ & 36 & 8 & 28 & 27 & 34 & 18 & 16 & 28 & & NR & & \\
\hline $\begin{array}{l}\text { Levetiracetam/ } \\
\text { Keppra }^{\circledR}(1999)\end{array}$ & $\begin{array}{l}3,000 \mathrm{mg} / \mathrm{day} \\
\text { (1500 mg bid) }\end{array}$ & $39, f$ & $7^{c, f}$ & 32 & 29,30 & $41^{c, f}$ & $14^{c, f}$ & 27 & 29,30 & $8.2^{c, f}$ & $0.5^{c, f}$ & 7.7 & 29,30 \\
\hline $\begin{array}{l}\text { Oxcarbazepine/ } \\
\text { Trileptal }^{\circledast}(2000)\end{array}$ & $\begin{array}{l}1,200 \mathrm{mg} / \text { day } \\
\text { (600 mg bid) }\end{array}$ & 40 & 8 & 32 & 31 & 41 & 13 & 28 & 32 & 10 & 0.6 & 9.4 & 32 \\
\hline $\begin{array}{l}\text { Perampanel/ } \\
\text { FycompaTM (2012) }^{\text {Th }}\end{array}$ & 12 mg/day (qd) & 27.2 & 12.8 & 14.4 & 33 & 35 & 19 & 16 & 34 & 4.1 & 1.0 & 3.1 & 33 \\
\hline $\begin{array}{l}\text { Pregabalin/ } \\
\text { Lyrica }^{\circledast}(2005)\end{array}$ & $\begin{array}{l}600 \mathrm{mg} / \text { day }(200 \mathrm{mg} \\
\text { tid or } 300 \mathrm{mg} \text { bid) }\end{array}$ & $44^{c, d}$ & $0^{c, d}$ & 45 & 35 & $47^{c, d}$ & $10^{c, d}$ & 37 & $36-38$ & 12 & 1.0 & 11 & 36 \\
\hline $\begin{array}{l}\text { Tiagabine/ } \\
\text { Gabitri| }^{\circledR} \text { (1998) }\end{array}$ & $\begin{array}{l}56 \text { mg/day (in } \\
2-4 \text { divided doses) }\end{array}$ & 36 & 3 & 33 & 39 & 30 & 4 & 26 & 39 & & NR & & \\
\hline $\begin{array}{l}\text { Topiramate/ } \\
\text { Topamax }^{\circledast} \text { (1996) }\end{array}$ & $\begin{array}{l}400 \mathrm{mg} / \mathrm{day} \\
(200 \mathrm{mg} \text { bid) }\end{array}$ & $45^{c, f}$ & $8^{c, f}$ & 37 & 40 & $41^{c, f}$ & $15^{c, f}$ & 26 & 40 & 8.7 & 0 & 8.7 & 41 \\
\hline $\begin{array}{l}\text { Zonisamide/ } \\
\text { Zonegran }{ }^{\circledast}(2000)\end{array}$ & $\begin{array}{l}400 \mathrm{mg} / \text { day } \\
\text { (200 mg bid) }\end{array}$ & 40 & 9 & 31 & 42 & 42 & 22 & 20 & 42 & 6.1 & 2.8 & 3.3 & 43 \\
\hline
\end{tabular}

with at least a $50 \%$ reduction in seizure frequency, a primary endpoint typically required by the European Medicines Agency [EMA]) or the median percent reduction from baseline in seizure frequency (a usual US Food and Drug Administration [FDA]-required primary outcome). A comparison of the median percent reductions in seizure frequency for newer AEDs commonly used as adjunctive treatment for focal seizures reveals a small range of differences in efficacy (see Table 1). Vigabatrin (VGB) (Sabri ${ }^{\circledR}$ ) and ezogabine (EZG)/retigabine (Potiga ${ }^{\circledR} /$ Trobalt $^{\circledR}$ ) are considered 'last resort' drugs, and are therefore not included in Table 1.17-43 VGB is indicated as adjunctive therapy only in patients with complex partial seizures who are unresponsive to treatment with other AEDs and for whom the risk for vision loss with VGB treatment outweighs the perceived benefits. ${ }^{44}$ EZG has also been linked with retinal abnormalities, potential vision loss, and blue skin discoloration; 45 it is currently unknown if the skin discoloration or retina pigmentation changes are reversible. ${ }^{46}$

The efficacy of the newer AEDs for refractory focal seizures has been compared in recently published systematic reviews and meta-analyses (see Table 1). ${ }^{47,48}$ Costa et al. found significant differences in responder rates (primary outcome) compared with placebo among patients with refractory focal seizures treated with OXC, LTG, TPM, GBP, pregabalin (PGB), levetiracetam (LEV), tiagabine (TGB), zonisamide (ZNS,) eslicarbazepine (ESL), or LCM; results were the same when the efficacy analysis was adjusted for baseline risk. ${ }^{47}$ Similar results were found by Gao et al. ${ }^{48}$ in a comparative analysis of adjunctive ESL, EZG, carisbamate (CAR), LCM, brivaracetam (BRV), and perampanel (PMP) versus placebo in patients with refractory focal seizures.
In the absence of head-to-head trials, indirect comparisons of AED efficacy can be used to guide clinical decisions. Results from a random-effects metaanalysis (based on relative measurements of treatment effect) showed significant differences in responder rates favoring TPM over the pooled net effect of the other AEDs; the least efficacious AEDS were GBP and LCM. ${ }^{47}$ When adjusted for baseline risk, TPM and LEV were most efficacious, while GBP and TGB were least efficacious. Gao et al. ${ }^{48}$ used a similar methodology to indirectly compare responder rates among the AEDs tested and found that ESL and BRV were the most efficacious; however, at the time of this publication BRV has not received FDA approval. ${ }^{48}$

Though it may be convenient to take these results at face value, such indirect comparisons can be complicated by many factors. In a systematic review and meta-analysis evaluating the possible effects of methodological differences in trial design and analyses on AED efficacy comparisons, it was determined that indirect efficacy comparisons are confounded by several factors, including length of efficacy evaluation, the trial phase used to determine responder rate (entire treatment phase [titration + maintenance] versus maintenance period), and the statistics used to calculate responder rate (last observation carried forward [LOCF] versus completer). ${ }^{49}$ Thus, results from such indirect efficacy comparisons should be approached with caution, and other factors must be considered when making treatment decisions.

\section{Seizure Freedom}

The ultimate goal of AED treatment is seizure freedom. Seizure freedom is often reported as the proportion of seizure-free patients or the proportion of seizure-free days during treatment. Since the analysis of seizure freedom is 
Table 2: Incidence ( $\geq 15 \%$ for Any Drug) of Treatment-emergent Adverse Events Associated With Newer Antiepileptic Drugs for Adjunctive Therapy

\begin{tabular}{|c|c|c|c|c|c|c|c|c|c|c|c|}
\hline $\begin{array}{l}\text { Preferred Term } \\
\% \text { drug/PBO }\end{array}$ & $\begin{array}{l}\text { ESL (800- } \\
1,200 \text { mg/day) }\end{array}$ & $\mathrm{GBP}^{\mathrm{a}}$ & $\begin{array}{l}\text { LCM (200- } \\
400 \text { mg/day) }\end{array}$ & LEV $^{\mathrm{a}}$ & LTG $^{a}$ & $\begin{array}{l}\text { OXC (600- } \\
1,200 \text { mg/day) }\end{array}$ & $\begin{array}{l}\text { PMP (4-12 } \\
\text { mg/day) }\end{array}$ & $\begin{array}{l}\text { PGB (150- } \\
600 \text { mg/day) }\end{array}$ & $\mathrm{TGB}^{\mathrm{a}}$ & $\begin{array}{l}\text { TPM (200- } \\
400 \text { mg/day) }\end{array}$ & $\mathrm{ZNS}^{\mathrm{a}}$ \\
\hline & $\mathrm{n}=825$ & $n=543$ & $\mathrm{n}=741$ & $n=769$ & $n=711$ & $n=334$ & $n=858$ & $\mathrm{n}=670$ & $n=494$ & $n=183$ & $n=269$ \\
\hline \multicolumn{12}{|l|}{ Nervous System } \\
\hline Asthenia & $2 / 2$ & & $2 / 1$ & $15 / 9$ & & $4 / 5$ & $2 / 1$ & & $20 / 14$ & $6 / 1$ & \\
\hline Ataxia & $5 / 2$ & $12 / 6$ & $6 / 2$ & $3 / 1$ & $22 / 6$ & $13 / 5$ & $4 / 0$ & $15 / 4$ & $5 / 3$ & $16 / 7$ & $6 / 1$ \\
\hline Dizziness & $24 / 9$ & $17 / 7$ & $25 / 8$ & $9 / 4$ & $38 / 13$ & $29 / 13$ & $32 / 9$ & $32 / 11$ & $27 / 15$ & $25 / 15$ & $13 / 7$ \\
\hline Headache & $14 / 9$ & & $13 / 9$ & $14 / 13$ & $29 / 19$ & $30 / 23$ & $12 / 11$ & & & & $10 / 8$ \\
\hline Nervousness & & $2 / 2$ & & $4 / 2$ & & $3 / 1$ & & & $10 / 3$ & $16 / 6$ & $2 / 1$ \\
\hline Somnolence & $14 / 8$ & $19 / 9$ & $7 / 5$ & $15 / 8$ & $14 / 7$ & $24 / 12$ & $15 / 7$ & $22 / 11$ & $18 / 15$ & $29 / 12$ & $17 / 7$ \\
\hline \multicolumn{12}{|c|}{ Digestive System } \\
\hline Nausea & $13 / 5$ & & $10 / 4$ & & $19 / 10$ & $20 / 10$ & $6 / 5$ & & $11 / 9$ & $10 / 8$ & $9 / 6$ \\
\hline Vomiting & $8 / 3$ & & $8 / 3$ & & $9 / 4$ & $19 / 5$ & $3 / 3$ & & $7 / 3$ & & \\
\hline \multicolumn{12}{|c|}{ General Disorders/Body as a Whole } \\
\hline Fatigue & $5 / 4$ & $11 / 5$ & $7 / 6$ & & & $13 / 7$ & $9 / 5$ & & & $15 / 13$ & $8 / 6$ \\
\hline \multicolumn{12}{|c|}{ Eye Disorders/Special Senses } \\
\hline Diplopia & $10 / 2$ & $6 / 2$ & $9 / 2$ & $2 / 1$ & $28 / 7$ & $22 / 5$ & $2 / 1$ & $9 / 4$ & & $10 / 5$ & $6 / 3$ \\
\hline
\end{tabular}

Adverse events presented in respective prescribing information (PI) are those that occurred with an incidence $\geq 2 \%$ and greater than placebo; $17,22,23,27,31,34,35,39,40,42,52$ blank cells indicate data not reported in PI; BOLD indicates highest relative incidence among the antiepileptic drugs included in this comparison. ${ }^{a}$ Doses not specified in PI, reported for all approved doses combined. $E S L=$ eslicarbazepine; $G B P=$ gabapentin; $L C M=$ lacosamide; $L E V=$ levetiracetam; $L T G=$ lamotrigine; $O X C=O X C a r b a z e p i n e ; P B O=p l a c e b o ; P G B=$ pregabalin; $P I=$ prescribing information; $P M P=$ perampanel; $T G B=$ tiagabine; $T P M=$ topiramate; $Z N S=$ zonisamide.

not standard, nor has it been a primary endpoint in most clinical trials to date, any comparisons of seizure freedom rates among AEDS can be misleading and may be difficult due to methodological differences. With these caveats in mind, seizure freedom rates among several AEDs have been compared using a 'pragmatic intent-to-treat (ITT)' approach. ${ }^{50}$ Gazzola et al. found that seizure freedom rates (proportion of seizure-free patients) among those treated with OXC, GBP, LTG, LEV, PGB, and ZNS were low, ranging from $\leq 1.0 \%$ (ZNS, LTG) to $6.4 \%$ (LEV)..$^{50}$ Using an LOCF approach, seizure freedom rates in the same trials were found to be falsely inflated, serving as an example of the complexity and difficulty of such comparisons. ${ }^{50}$ Of the newer AEDs for which seizure freedom is reported in the pivotal trials, PGB has the highest rate versus placebo, followed by OXC, TPM, and LEV (see Table 1).

In the same random-effects meta-analysis described above, seizure freedom rates (available for 32 of 63 studies) showed no significant differences among the AEDs tested, but all AEDs had a more favorable response than placebo. By combining indirect and direct evidence from eight head-tohead trials, comparisons of seizure freedom rates favored TPM over LTG, while no differences were detected between LTG and either PGB or LEV.47 An additional meta-analysis found seizure freedom rates favoring all AEDS over placebo, with outcomes favoring LCM over ESL, EZG, CAR, BRV, and PMP. ${ }^{48}$ Again, differences in parameters and assumptions can limit the ability to show a clinically meaningful difference in seizure freedom rates among the AEDS.

Taken together, direct and indirect comparisons indicate few if any differences in efficacy of one newer AED over another, underscoring the importance of other factors that contribute to drug effectiveness and treatment success.

\section{Safety and Tolerability}

Though efficacy varies little among the newer third- and second-generation AEDs — and is similar to the first generation AEDS (e.g., VPA, CBZ) ${ }^{51}$-the newer AEDs are often advantageous with respect to tolerability, having fewer side effects, and a lower risk for drug-drug and hypersensitivity interactions than older AEDs.?

\section{Adverse Events}

The potential for adverse events (AES) with a particular AED may be a strong differentiating factor when making treatment decisions. Most AEs are manageable, only requiring dose adjustments or a change in drug formulation, e.g., from immediate-release to XR. Overall, the newer AEDS have few worrisome side effects. AEs most commonly associated with the newer AEDS are neurological or gastrointestinal effects, including dizziness, ataxia, somnolence, and nausea (see Table 2).

In addition to the common AEs identified in Table 2, select 'Warnings and Precautions' that may further distinguish one AED over another are listed in Table 3. Patients treated with ESL have had drug reaction with eosinophilia and systemic symptoms (DRESS), also known as multiorgan hypersensitivity; kidney stones can occur with TPM and ZNS; LEV52 and PMP have been linked to psychiatric symptoms and behavioral issues; cognitive dysfunction or depression and mood problems have been reported with TPM; and weight gain with PGB, PMP, and GBP may be a differentiating factor. Not listed in Table 3 (since it appears in the prescribing information [PI] for each AED and would therefore not be a distinguishing factor) are suicidality and the potential for increased seizure frequency with rapid withdrawal. Two of the newer AEDS also carry black box warnings on their labeling for rare and idiosyncratic reactions: LTG for serious skin rashes (including Stevens-Johnson syndrome and toxic epidermal necrolysis); PMP for life-threatening psychiatric and behavioral reactions (including aggression, hostility, irritability, anger, and homicidal ideation). ${ }^{53}$

In the random-effects meta-analysis, six pre-specified AEs were compared among the newer AEDs: ataxia, headache, dizziness, fatigue, nausea, and somnolence. Overall, few differences between AEDs were found: 
Table 3: Select Warnings and Precautions Identified in Prescribing Information ${ }^{a}$

\begin{tabular}{|c|c|}
\hline Drug/Brand Name & Warnings and Precautions \\
\hline Eslicarbazepine/Aptiom ${ }^{\circledR}$ & $\begin{array}{l}\text { Anaphylactic reactions and angioedema } \\
\text { DRESS/multi-organ hypersensitivity } \\
\text { Serious dermatologic reactions } \\
\text { Drug-induced liver injury }\end{array}$ \\
\hline Gabapentin/Neurontin ${ }^{\circledR}$ & $\begin{array}{l}\text { Behavioral problems, hostility (including aggressive behaviors) in pediatrics } \\
\text { Thought disorders (including concentration problems and change in school performance) in pediatrics } \\
\text { Hyperkinesia (primarily restlessness and hyperactivity) in pediatrics } \\
\text { DRESS/multi-organ hypersensitivity }\end{array}$ \\
\hline Lacosamide/Nimpat ${ }^{\circledR}$ & $\begin{array}{l}\text { Dizziness and ataxia } \\
\text { Caution for patients with known cardiac conduction problems, severe cardiac disease, or who are taking drugs known to prolong the QT interval }\end{array}$ \\
\hline Lamotrigine/Lamictal ${ }^{\circledR}$ & $\begin{array}{l}\text { Serious rash/rash-related death } \\
\text { Fatal or life-threatening multi-organ hypersensitivity } \\
\text { Blood dyscrasias } \\
\text { Aseptic meningitis }\end{array}$ \\
\hline Levetiracetam/Keppra ${ }^{\circledR}$ & $\begin{array}{l}\text { Psychiatric symptoms: psychotic symptoms, irritability, and aggressive behavior } \\
\text { Somnolence and fatigue }\end{array}$ \\
\hline Oxcarbazepine/Trileptal ${ }^{\circledR}$ & $\begin{array}{l}\text { Hyponatremia } \\
\text { Anaphylactic reactions and angioedema } \\
\text { Serious dermatologic reactions } \\
\text { Psychomotor slowing, difficulty with concentration, and speech or language problems } \\
\text { Ataxia and gait disturbances } \\
\text { Hematologic events }\end{array}$ \\
\hline Perampanel/Fycompa ${ }^{\circledR}$ & $\begin{array}{l}\text { Hostility and aggression } \\
\text { Dizziness and gait disturbance } \\
\text { Falls }\end{array}$ \\
\hline Pregabalin/Lyrica ${ }^{\circledR}$ & $\begin{array}{l}\text { Angioedema } \\
\text { Hypersensitivity reactions (hives, dyspnea, and wheezing) } \\
\text { Peripheral edema } \\
\text { Weight gain }\end{array}$ \\
\hline Tiagabine/Gabitril ${ }^{\circledR}$ & $\begin{array}{l}\text { Impaired concentration, speech or language problems, and confusion } \\
\text { Binding in the eye and other melanin-containing tissues } \\
\text { Serious rash }\end{array}$ \\
\hline Topiramate/Topamax ${ }^{\circledR}$ & $\begin{array}{l}\text { Kidney stones } \\
\text { Cognitive dysfunction or depression/mood problems } \\
\text { Acute myopia and secondary angle closure glaucoma (can lead to permanent vision loss if left untreated) } \\
\text { Visual field defects } \\
\text { Oligohidrosis and hyperthermia } \\
\text { Metabolic acidosis } \\
\text { Hyperammonemia }\end{array}$ \\
\hline Zonisamide/Zonegran ${ }^{\circledR}$ & $\begin{array}{l}\text { Kidney stones/effect on renal function } \\
\text { Potentially fatal reaction to sulfonamides, including Stevens-Johnson syndrome, toxic epidermal necrolysis, fulminant hepatic } \\
\text { necrosis, agranulocytosis, and aplastic anemia/other blood dyscrasias } \\
\text { Oligohidrosis and hyperthermia in pediatrics } \\
\text { Depression and psychosis } \\
\text { Psychomotor slowing, difficulty with concentration, and speech or language problems (particularly word-finding) } \\
\text { Creatine phosphokinase elevation and pancreatitis }\end{array}$ \\
\hline
\end{tabular}

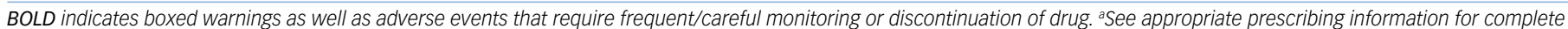
information on warnings and precautions for each drug. 17,22,23,27,31,34,35,39,40,42,52 DRESS = drug reaction with eosinophilia and systemic symptoms.

Ataxia: no difference

Headache: $\uparrow$ LCM

Dizziness: $\uparrow P G B$

In addition to $A E$ incidence, patient withdrawal due to AEs for a particular AED can be a good indicator of tolerability. Withdrawals due to AEs were greater than placebo for all AEDS. ${ }^{47}$ Comparison of each AED to the pooled effect of the others revealed significantly fewer withdrawals due to AES with LEV; no differences among the other AEDS were detected. ${ }^{47}$

\section{Drug-Drug Interactions and Comorbidities}

Important factors to consider when making treatment decisions for the patient with focal epilepsy are the risk for drug-drug interactions and the presence of comorbid conditions. AEDs are among the most complex class of drugs in terms of pharmacokinetic properties and are 
Table 4: Known Drug Interactions ${ }^{a}$ With Newer Antiepileptic Drugs

\begin{tabular}{|c|c|c|c|}
\hline Drug/Brand Name & $\begin{array}{l}\text { Enzyme } \\
\text { Inducer }\end{array}$ & Drugs that Change Antiepileptic Drug Plasma Levels & $\begin{array}{l}\text { Drugs that Are/May Be Affected by } \\
\text { Antiepileptic Drugs }\end{array}$ \\
\hline Eslicarbazepine/Aptiom ${ }^{\circledast}$ & Yes $^{b}$ & $\mathrm{CBZ}, \mathrm{PB}, \mathrm{PHT}$ reduce ESL concentration & $\begin{array}{l}\text { CBZ } \\
\text { Ethinylestradiol/levonorgestrel } \\
\text { PHT } \\
\text { Statins } \\
\text { S-warfarin }\end{array}$ \\
\hline Gabapentin/Neurontin ${ }^{\circledast}$ & No & $\begin{array}{l}\text { Cimetidine decreases mean apparent oral clearance of GBP by } 14 \% \\
\text { Hydrocodone increases GBP AUC by } 14 \% \\
\text { Maalox reduces the bioavailability of GBP by } 20 \% \\
\text { Morphine increases mean GBP AUC by } 44 \% \\
\text { Naproxen increases GBP absorption by } 12-15 \%\end{array}$ & $\begin{array}{l}\text { Hydrocodone } \\
\text { Norethindrone }\end{array}$ \\
\hline Lacosamide/Vimpat ${ }^{\circledR}$ & No & None & Ethinylestradiol \\
\hline Lamotrigine/Lamictal $^{\circledast}$ & No & $\begin{array}{l}\text { CBZ, PB, PHT, and rifampin decrease LTG concentration by } 40 \% \\
\text { Oral contraceptives decrease LTG concentration by } 50 \% \\
\text { VPA increases LTG concentration more than twofold }\end{array}$ & $\begin{array}{l}\text { Levonorgestrel } \\
\text { VPA }\end{array}$ \\
\hline Levetiracetam/Keppra ${ }^{\circledast}$ & No & None & None \\
\hline Oxcarbazepine/Trileptal ${ }^{\oplus}$ & Yes $^{\mathrm{b}}$ & $\begin{array}{l}\text { CBZ decreases MHDc concentration by } 40 \% \\
\text { PB decreases MHDc concentration by } 25 \% \\
\text { PHT decreases MHD concentration by } 30 \% \\
\text { Verapamil decreases MHD concentration by } 20 \% \\
\text { VPA decreases MHD concentration by } 18 \%\end{array}$ & $\begin{array}{l}\text { Cyclosporine } \\
\text { Ethinylestradiol/levonorgestrel } \\
\text { Felodipine } \\
\text { PB } \\
\text { PHT }\end{array}$ \\
\hline Perampanel/Fycompa ${ }^{\circledast}$ & No & $\begin{array}{l}\text { CBZ reduces PMP AUC by } 67 \% \\
\text { Ketoconazole increases PMP AUC by } 20 \% \\
\text { OXC reduces PMP AUC by } 50 \% \\
\text { PHT reduces PMP AUC by } 50 \% \\
\text { Rifampin and St John's wort can reduce PMP levels } \\
\text { TPM reduces PMP AUC by } 20 \%\end{array}$ & $\begin{array}{l}\text { Alcohol/ CNS depressants } \\
\text { Levonorgestrel } \\
\text { Midazolam } \\
\text { OXC }\end{array}$ \\
\hline Pregabalin/Lyrica ${ }^{\circledast}$ & No & None & None \\
\hline Tiagabine/Gabitril ${ }^{\circledast}$ & No & $\begin{array}{l}\mathrm{CBZ}, \mathrm{PHT} \text {, and PB increase TGB clearance by } 60 \% \\
\text { VPA increases free TGB concentration by } 40 \% \text { in vitro }\end{array}$ & VPA \\
\hline Topiramate/Topamax ${ }^{\circledR}$ & Yes $^{b}$ & $\begin{array}{l}\text { CBZ decreases TPM concentration by } 40 \% \\
\text { LTG decreases TPM concentration by } 13 \% \\
\text { PHT decreases TPM concentration by } 48 \% \\
\text { VPA decreases TPM concentration by } 14 \%\end{array}$ & $\begin{array}{l}\text { Alcohol/CNS depressants } \\
\text { Amitriptyline } \\
\text { Diltiazem } \\
\text { Ethinylestradiol } \\
\text { Glyburide } \\
\text { Hydrochlorothiazide } \\
\text { Lithium } \\
\text { Metformin } \\
\text { PHT } \\
\text { VPA }\end{array}$ \\
\hline Zonisamide/Zonegran ${ }^{\circledast}$ & No & $\begin{array}{l}\mathrm{PHT}, \mathrm{CBZ} \text {, and PB increase metabolism/clearance and decrease } \\
\text { the half-life of ZNS }\end{array}$ & None \\
\hline
\end{tabular}

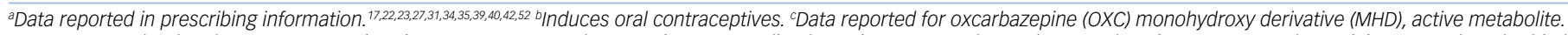

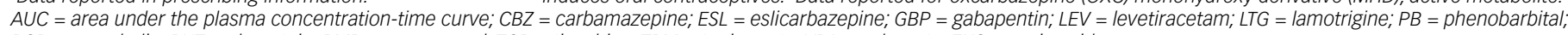
$P G B=$ pregabalin; $P H T=$ phenytoin; $P M P=$ perampanel; $T G B=$ tiagabine; $T P M=$ topiramate; $V P A=$ valproate; $Z N S=$ ZOnisamide

some of the leading medications responsible for drug-drug interactions. ${ }^{54}$ Risk for drug interactions are especially high in the elderly, as most elderly epilepsy patients take an average of seven prescription medications. ${ }^{55}$

As a group, the newer AEDs are less likely to cause adverse drug interactions because most do not induce the CYP450 enzyme system, the main culprit of drug-drug interactions (see Table 4). Induction of hepatic CYP isozymes increases drug metabolism as well as the metabolism of endogenous compounds, including free fatty acids, steroids, vitamin D, and prostaglandins. ${ }^{54,56,57}$ Concerns have been raised regarding older, commonly prescribed enzyme-inducing AEDS (CBZ, PHT, and phenobarbital
[PB]) due to their effects in reducing the action of many classes of drugs, such as statins, oral contraceptives, analgesics, antiarrhythmics, and immunosuppressants. ${ }^{56}$ Treatment with older AEDs therefore has the potential for serious consequences in patients with comorbid conditions such psychiatric disorders, HIV/AIDS, cancer, and diabetes.

French and Gidal explored the effects of newer AEDs on drug serum concentrations of older AEDs and vice versa. ${ }^{54}$ This study and the data reported in specific PIs showed that most newer AEDS (GBP, LTG, LEV, OXC, $P G B, T G B, T P M)$ have no effect on the drug plasma concentrations of older AEDS (CBZ, PB, PHT, primidone, VPA), with the exception of an increase 


\section{Table 5: Indications, Formulations, and Cost of Newer Antiepileptic Drugs}

\begin{tabular}{|c|c|c|c|c|c|c|c|c|}
\hline $\begin{array}{l}\text { Drug/Brand } \\
\text { Name }\end{array}$ & $\begin{array}{l}\text { Indication for Adjunctive } \\
\text { Focal (Partial-Onset) } \\
\text { Seizures }\end{array}$ & Other Indications & $\begin{array}{l}\text { Maximum } \\
\text { Approved }^{\text {Dose }}\end{array}$ & $\begin{array}{l}\text { Type of Formulation } \\
\text { (Strengths) }\end{array}$ & $\begin{array}{l}\text { Cost }^{\mathrm{b}} \\
\text { Brand }\end{array}$ & Generic & \multicolumn{2}{|c|}{$\begin{array}{l}\text { No. Daily Tablets or } \\
\text { Capsule to Reach } \\
\text { Maximum Dose } \\
\text { Brand Generic }\end{array}$} \\
\hline \multicolumn{9}{|c|}{ Immediate-release Formulations } \\
\hline $\begin{array}{l}\text { Eslicarbazepine/ } \\
\text { Aptiom }^{\circledast}\end{array}$ & Adult patients & NONE & 1,200 mg/day & $\begin{array}{l}\text { Tablets }(200,400, \\
600,800 \mathrm{mg})\end{array}$ & $\$ 1,294.71$ & NA & 2 & NA \\
\hline $\begin{array}{l}\text { Gabapentin/ } \\
\text { Neurontin }^{\circledR}\end{array}$ & Patients $\geq 3 y$ & $\begin{array}{l}\text { Postherpetic neuralgia } \\
\text { (adults) }\end{array}$ & $\begin{array}{l}\text { 1,800 mg/day } \\
\text { (600 mg tid) }\end{array}$ & $\begin{array}{l}\text { Tablets (600, } 800 \mathrm{mg}) \\
\text { Capsules (100, 300, } 400 \mathrm{mg}) \\
\text { Oral solution (250 mg/5 ml) }\end{array}$ & $\$ 483.02$ & $\$ 21.52$ & 3 & 3 \\
\hline $\begin{array}{l}\text { Lacosamide/ } \\
\text { Vimpat }^{\circledR}\end{array}$ & $\begin{array}{l}\text { Tablets, oral solution ( } \geq 17 y) \\
\text { Injection for IV use ( } \geq 17 y)\end{array}$ & Monotherapy for POS ( $\geq 17 y)$ & $\begin{array}{l}400 \text { mg/day } \\
\text { (200 mg bid) }\end{array}$ & $\begin{array}{l}\text { Tablets }(50,100,150,200 \mathrm{mg}) \\
\text { Oral solution }(10 \mathrm{mg} / \mathrm{ml}) \\
\text { Single-use vial }(200 \mathrm{mg} / 20 \mathrm{ml})\end{array}$ & $\$ 652.57$ & NA & 2 & NA \\
\hline $\begin{array}{l}\text { Lamotrigine/ } \\
\text { Lamictal }^{\circledR}\end{array}$ & Patients $\geq 2 y$ & $\begin{array}{l}\text { Adjunctive therapy for PGTC and LGS ( } \geq 2 \mathrm{y}) \\
\text { Conversion to monotherapy for POS } \\
(\geq 16 \mathrm{y}) \text { in patients with CBZ, PB, PHT, } \\
\text { primidone, or VPA monotherapy } \\
\text { Bipolar I disorder ( } \geq 18 \mathrm{y} \text { ) to delay mood } \\
\text { episodes in patients treated for acute } \\
\text { mood episodes with ST }\end{array}$ & $\begin{array}{l}500 \mathrm{mg} / \text { day } \\
\text { (in } 2 \text { divided } \\
\text { doses) }\end{array}$ & $\begin{array}{l}\text { Tablets }(25,100,150,200 \mathrm{mg}) \\
\text { Chewable dispersible tablets } \\
(2,5,25 \mathrm{mg}) \\
\text { Orally disintegrating tablets } \\
(25,50,100,200 \mathrm{mg})\end{array}$ & $\$ 850.95$ & $\$ 18.90$ & 3 & 3 \\
\hline $\begin{array}{l}\text { Levetiracetam/ } \\
\text { Keppra }^{\circledR}\end{array}$ & $\begin{array}{l}\text { Injection for IV use ( } \geq 16 y) \\
\text { Tablets, oral solution } \\
\text { ( } \geq 1 \text { month) }\end{array}$ & $\begin{array}{l}\text { Adjunctive therapy for myoclonic } \\
\text { seizures ( } \geq 12 \text { y with JME) } \\
\text { Adjunctive therapy PGTC } \\
\text { ( } \geq 6 \text { y with IGE) }\end{array}$ & $\begin{array}{l}3,000 \mathrm{mg} / \text { day } \\
(1,500 \mathrm{mg} \text { bid })\end{array}$ & $\begin{array}{l}\text { Tablets }(250,500,750, \\
1,000 \mathrm{mg}) \text { oral solution } \\
(100 \mathrm{mg} / \mathrm{ml}) \\
\text { Single-use vial }(500 \mathrm{mg} / 5 \mathrm{ml})\end{array}$ & $\$ 1,039.53$ & $\$ 51.82$ & 4 & 4 \\
\hline $\begin{array}{l}\text { Oxcarbazepine/ } \\
\text { Trileptal }{ }^{\circledR}\end{array}$ & Patients $\geq 2 y$ & Monotherapy for partial seizures ( $\geq 4 y$ ) & $\begin{array}{l}1,200 \mathrm{mg} / \text { day } \\
\text { (600 mg bid) }\end{array}$ & $\begin{array}{l}\text { Tablets }(150,300,600 \text { mg) } \\
\text { Oral suspension (60 mg/ml) }\end{array}$ & $\$ 598.62$ & $\$ 27$ & 2 & 2 \\
\hline $\begin{array}{l}\text { Pregabalin/ } \\
\text { Lyrica }^{\circledR}\end{array}$ & Adult patients & $\begin{array}{l}\text { Neuropathic pain associated with DPN } \\
\text { Postherpetic neuralgia } \\
\text { Fibromyalgia } \\
\text { Neuropathic pain associated } \\
\text { with spinal cord injury }\end{array}$ & $\begin{array}{l}600 \text { mg/day } \\
\text { (300 mg bid } \\
\text { or } 200 \text { mg tid) }\end{array}$ & $\begin{array}{l}\text { Capsules }(25,50,75,100 \\
150,200,225,300 \mathrm{mg}) \\
\text { Oral solution }(20 \mathrm{mg} / \mathrm{ml})\end{array}$ & $\begin{array}{l}\$ 272.00 \\
\text { (bid) } \\
\$ 398.35 \\
\text { (tid) }\end{array}$ & NA & $\begin{array}{l}2 \text { (bid) } \\
3 \text { (tid) }\end{array}$ & NA \\
\hline $\begin{array}{l}\text { Perampanel/ } \\
\text { Fycompa }^{\circledR}\end{array}$ & Patients $\geq 12 y$ & NONE & 12 mg/day & Tablets $(2,4,6,8,10,12 \mathrm{mg})$ & $\$ 617.46$ & NA & 1 & NA \\
\hline $\begin{array}{l}\text { Tiagabine/ } \\
\text { Gabitril }^{\circledR}\end{array}$ & Patients $\geq 12 y$ & NONE & $\begin{array}{l}56 \text { mg/day } \\
\text { (in 2-4 divided } \\
\text { doses) }\end{array}$ & Tablets $(2,4,12,16 \mathrm{mg})$ & $\$ 1,357.66$ & $\$ 963.69$ & 5 & $14^{c}$ \\
\hline $\begin{array}{l}\text { Topiramate/ } \\
\text { Topamax }^{\circledast}\end{array}$ & Patients $\geq 2 y$ & $\begin{array}{l}\text { Adjunctive therapy for PGTC and LGS ( } \geq 2 \mathrm{y} \text { ) } \\
\text { Initial monotherapy for POS and PGTC ( } \geq 2 \mathrm{y}) \\
\text { Prophylaxis for migraine } \\
\text { headaches (adults) }\end{array}$ & $\begin{array}{l}400 \text { mg/day } \\
\text { (200 mg bid) }\end{array}$ & $\begin{array}{l}\text { Tablets }(25,50,100,200 \text { mg) } \\
\text { Sprinkle capsules }(15,25 \text { mg) }\end{array}$ & $\$ 808.26$ & $\$ 15.22$ & 2 & 2 \\
\hline $\begin{array}{l}\text { Zonisamide/ } \\
\text { Zonegran }^{\circledR}\end{array}$ & Adult patients & NONE & $\begin{array}{l}400 \text { mg/day } \\
\text { (200 mg bid) }\end{array}$ & Capsules $(25,50,100$ mg) & $\$ 725.75$ & $\$ 28.80$ & 4 & 4 \\
\hline \multicolumn{9}{|c|}{ Extended-release Formulations } \\
\hline $\begin{array}{l}\text { Lamotrigine/ } \\
\text { Lamictal }^{\circledR} \mathrm{XR}^{\mathrm{TM}}\end{array}$ & Patients $\geq 13 y$ & $\begin{array}{l}\text { Adjunctive therapy for PGTC ( } \geq 13 y) \\
\text { Conversion to monotherapy for POS } \\
\text { patients receiving treatment with a } \\
\text { single AED ( } \geq 13 y \text { ) }\end{array}$ & $\begin{array}{l}250 \mathrm{mg} / \text { day }^{\mathrm{d}} \\
400 \mathrm{mg} / \text { day }^{\mathrm{e}} \\
600 \mathrm{mg} / \text { day }^{\mathrm{f}}\end{array}$ & $\begin{array}{l}\text { XR tablets }(25,50,100, \\
200,250,300 \mathrm{mg})\end{array}$ & $\begin{array}{l}\$ 603.43^{d} \\
\$ 885.68^{e} \\
\$ 1,345.99^{f}\end{array}$ & $\begin{array}{l}\$ 215.54^{\mathrm{d}} \\
\$ 312.62^{\mathrm{e}} \\
\$ 465.19^{\mathrm{f}}\end{array}$ & $\begin{array}{l}1 \\
2 \\
2\end{array}$ & $\begin{array}{l}1 \\
2 \\
2\end{array}$ \\
\hline $\begin{array}{l}\text { Levetiracetam/ } \\
\text { Keppra XR }\end{array}$ & Patients $\geq 12 y$ & NONE & 3,000 mg/day & XR tablets $(500,750 \mathrm{mg})$ & $\$ 1,044.37$ & $\$ 82.54$ & 4 & 4 \\
\hline $\begin{array}{l}\text { Oxcarbazepine/ } \\
\text { Oxtellar XRTM }\end{array}$ & Patients $\geq 6 y$ & NONE & 2,400 mg/day & $\begin{array}{l}\text { XR tablets }(150,300 \text {, } \\
600 \mathrm{mg})\end{array}$ & $\$ 1,070.84$ & NA & 4 & NA \\
\hline $\begin{array}{l}\text { Topiramate/ } \\
\text { Qudexy'M XR }\end{array}$ & Patients $\geq 2 y$ & $\begin{array}{l}\text { Monotherapy for POS or PGTC ( } \geq 10 y) \\
\text { Adjunctive therapy for PGTC or LGS }(\geq 2 y)\end{array}$ & 400 mg/day & $\begin{array}{l}\text { XR capsules, intact or sprinkle } \\
(25,50,100,150,200 \mathrm{mg})\end{array}$ & NA & NA & 2 & NA \\
\hline $\begin{array}{l}\text { Topiramate/ } \\
\text { Trokendi XR }\end{array}$ & Patients $\geq 6 y$ & $\begin{array}{l}\text { Monotherapy for POS and PGTC ( } \geq 10 y) \\
\text { Adjunctive therapy for PGTC or LGS }(\geq 2 y)\end{array}$ & 400 mg/day & $\begin{array}{l}\text { XR capsules }(25,50, \\
100,200 \mathrm{mg})\end{array}$ & $\$ 1206.96$ & NA & 2 & NA \\
\hline
\end{tabular}

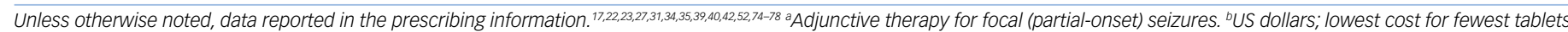
or capsule needed to reach maximum approved daily dose per 30 days. Data from www.GoodRx.com ${ }^{80}$ using Chicago-area zipcode, 60601. Accessed on June 18, 2014. ${ }^{\circ}$ Generic only

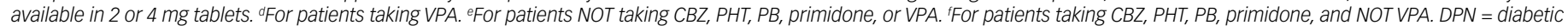
peripheral neuropathy; IGE = idiopathic generalized epilepsy; JME = juvenile myoclonic epilepsy; LGS = Lennox-Gastaut Syndrome; PGTCS = primary generalized tonic-clonic seizures; $P O S=$ partial-onset seizures; $S T=$ standard therapy; $X R=$ extended release; $y=$ year. 
in $\mathrm{PHT}$ and decrease in $\mathrm{CBZ}$ with $\mathrm{ESL}$, increases in $\mathrm{PB}$ and $\mathrm{PHT}$ with $\mathrm{OXC}$ a decrease in VPA with LTG, decrease in VPA with TGB, and a possible increase in PHT and decrease in VPA with TPM. 17,39,40,54 Conversely, drug plasma levels of many of the newer AEDs were decreased by the addition of older AEDs. None of the older AEDs had an effect on GBP, LEV, or PGB. ${ }^{54}$

Overall, VPA had the least effect on newerAED drug plasma concentrations ${ }^{54}$; however, when combined with LTG, dose adjustments may be required since VPA increases LTG plasma concentrations by decreasing LTG clearance (see Lamictal $^{\circledR}$ PI for specific dosing recommendations of LTG in combination with various AEDS ${ }^{27}$ ). The effect of drugs that are known to change plasma levels of the newer AEDs, and a list of drugs that are affected by the newer AEDs as reported in the PIs, are provided in Table 4.

Since newer AEDs are equivalent or nearly equivalent in efficacy ${ }^{58}$ without the risks associated with the older enzyme-inducing AEDs, prudence dictates that newer AEDs be used preferentially, reserving enzymeinducing AEDS as a last resort.

\section{Pregnancy}

The choice of AED for women of child-bearing age was once thought to be crucial given the known effects of VPA on fetal $\operatorname{cognition}^{59}$ and the increased risk for malformations with AED use, especially if the fetus is exposed during organogenesis. While the overall risk for malformations with AEDS are double that of untreated pregnancies and tripled when AEDs are combined (particularly when VPA is one of them), ${ }^{60}$ recent results from AED pregnancy registries reveal that most newer AEDs can be taken with relatively low risk to the developing fetus. In a recent comparative safety analysis of pregnant women enrolled in the North American AED Pregnancy Registry between 1997 and 2011, VPA led to a higher risk for neural tube defects, cardiac defects, hypospadias, and oral clefts, and TPM was associated with cleft lip (1.4\% of infants)..61 The risk for major malformations was low for ZNS (0 \%), LEV (2.4\%), and LTG (2.0\%); moderate with TPM (4.2\%); and highest with VPA (9.3\%)..$^{61}$ All of the newer AEDS are Pregnancy Category Class $C$ drugs with the exception of TPM, which is a Class D drug and should be used during pregnancy only when there is a clear benefit that outweighs the potential harm to the fetus. ${ }^{40}$

\section{Effectiveness-The Balance Between Efficacy and Tolerability}

Retention rates (proportion of patients remaining on treatment) can indicate the long-term tolerability and effectiveness of a particular drug. Longterm retention rates of the newer AEDs have been reported in numerous publications. Overall, 1-year retention rates were greatest in patients treated with LTG (79 \% ${ }^{62}$ and $\left.40 \%-60 \%{ }^{63}\right)$, LEV $(60 \%-75 \%),{ }^{62,63}$ and TPM (40 \%-60 \%). ${ }^{63}$ The greatest 2-year retention rates found were in patients treated with OXC $(85 \%)^{64}$ and LTG $(74 \%){ }^{65}$ Three-year retention was highest with LTG (74 \%) followed by TPM (64 \%), GBP (42 \%), and TGB (38 \%). 66

\section{Drug Administration-Titration, Dosing, and Drug Formulations}

One of the most important reasons for low drug effectiveness is patient non-adherence to their treatment regimen. ${ }^{67}$ Patients that are not fully adherent to their AED treatment regimen have increased seizures and higher rates of morbidity and mortality. ${ }^{68-70}$ Poor adherence depends on several factors, including length of titration, dosing frequency, and drug formulation (tablet, capsule, liquid). There is little difference among AEDs in the time to reach steady-state/maintenance dose $(\sim 4$ weeks) with the exception of LTG and TPM, both requiring up to 8 weeks titration depending on dose-escalation strategy. In general, increased dosing frequency means reduced treatment adherence. In a systematic review, ${ }^{71}$ patient adherence was significantly greater with once-daily drug dosing versus three- and four-times daily dosing; a significant difference in adherence also was found in favor of twice-daily dosing versus fourtimes daily dosing, while no difference was detected between once- and twice-daily dosing.

Most patients prefer to take fewer daily doses of any medication. Extendedrelease (XR) or controlled-release (CR) drug formulations can simplify treatment and improve adherence by reducing dosing frequency, ${ }^{72}$ though the overall number of daily tablets or capsules may not differ greatly from immediate-release (IR) AEDs that need to be dosed more frequently (see Table 5). XR AEDS can alleviate breakthrough seizures and AEs caused by fluctuating plasma concentrations and peak-dose toxicity ${ }^{73}$ and may be preferable over IR formulations in patients who take drugs for other conditions. Newer AEDS that are available as XR formulations include LEV, LTG, OXC, and TPM. ${ }^{74-78}$

Intravenous (IV) formulations of AEDs are important during seizure emergencies-such as acute repetitive seizures, status epilepticus, and prolonged seizures. Both LCM and LEV are available as an IV formulation, though neither is technically approved for use in seizure emergencies. AEDs that are available as a liquid/syrup/oral solution (GBP, LEV, LCM, OXC, PGB), a chewable or orally disintegrating tablet (LTG), or a capsule that can be sprinkled onto food (TPM, Qudexy ${ }^{\mathrm{TM}} \mathrm{XR}$ ) are useful options for patients with swallowing difficulties.

\section{Food and Drug Administration Indications, Off- Label Use, Generics, and Cost}

Several of the newer AEDS are approved for indications other than the typical 'adjunctive therapy for focal seizures,' including TPM, GBP, OXC, LTG, and LEV. These 'multi-use' AEDs could be advantageous (and cost-effective) for patients with mixed seizure types and for those with comorbid conditions, such as bipolar disorder (LTG), postherpetic neuralgia (GBP and PGB), neuropathic pain or fibromyalgia (PGB), and migraine (TPM; see Table 5).

AEDs are prescribed for off-label use more than any other drug class (74 \% versus $60 \%$ for antipsychotics and $41 \%$ for antibiotics)..$^{79}$ Off-label prescribing is legal and is acknowledged by the FDA as an integral part of the practice of medicine. Of course, as also outlined by the FDA, off-label prescribing should be based 'on scientific rationale and on sound medical evidence ... maintain[ing] records of the product's use and effects.' AEDs can be used off-label within epilepsy and outside of epilepsy. Examples of off-label use outside of epilepsy include CBZ and OXC (bipolar disorder), GBP (pain associated with many disorders), PGB and TGB (anxiety), TPM (essential tremor), ZNS, and TPM (obesity). Example of off-label use within epilepsy would include monotherapy, primary generalized epilepsy, and use in children.

Use of generic AEDS, when available, can offer tremendous cost savings to patients ${ }^{80}$ (see Table 5), but it is important to understand that AEDs are 
unlike other drug classes in that small differences between formulations can have serious consequences, including breakthrough seizures and toxic side effects. ${ }^{81}$ Additionally, as generics only have to show bioequivalence to the branded drug, pharmacokinetic differences among generic products may also have serious consequences. Experts in the field recommend maintaining patients on a single generic manufacturer to minimize generic switching and the associated repercussions. ${ }^{82,83}$ The American Academy of Neurology (AAN) supports the use of the newer AEDS, but opposes generic substitution without attending physician approval. The AAN also opposes legislation requiring physicians to seek authorization prior to drug dispensing. ${ }^{81}$

\section{The Bottom Line-What Really Differentiates and What Helps Clinicians Choose a Drug?}

In the absence of large, observational studies to determine the long-term effectiveness of individual AEDs, clinicians must approach treatment decisions with a full perspective, considering and comparing the many factors that contribute to treatment success for an individual patient. The overall differences in efficacy among the newer AEDs-and between newer and older AEDs-do not clearly separate one drug from another. This is true for other drug classes (such as anxiolytics, antidepressants, and antipsychotics) and also largely for neurostimulation (vagal nerve stimulation, deep brain stimulation, and responsive neurostimulation). Based on currently available data and systematic analyses, other factors that do not clearly distinguish one new AED over another are pregnancy category, cost, and FDA-approved indications. Factors that may be helpful in choosing a specific AED for a particular patient include the type of dosing and formulation, as well as the titration schedule. A factor that clearly differentiates one AED from another is the presence of certain comorbid conditions. Additional differentiating factors include the potential for drug-drug interactions, safety, and tolerability with the newer AEDs being more desirable than the older, enzyme-inducing AEDS. Therefore, clinicians should first consider one of the newer AEDS (IR or XR) when making adjunctive treatment choices for patients with focal epilepsy.

\section{Making Treatment Choices-Illustrative Cases from Our Practice}

In order to provide real-life examples of the clinical challenges noted above, particularly for specialized populations, below are case reports from our practices that detail our thought processes in determining diagnosis and best course of treatment for these individual patients.

\section{Case 1. Episodes in Pediatric Patient Presentation}

A previously healthy 6-year-old boy fell asleep at his desk while at school. His teacher woke him up, but he was disoriented. He felt numbness and tingling in the left side of his face, realized he had dropped a pen, went to pick it up and fell out of his chair. While on the ground, the teacher described him to be rigid, in a fetal position with clenched hands and teeth. His eyes were rolled up, and he was drooling. This lasted approximately 3 minutes, and he returned to baseline within 30 minutes. He was seen at a local Emergency Department where a head computed tomography (CT), a comprehensive metabolic panel and urine toxicology screen were all normal. He was discharged without medications, with a diagnosis of a new onset seizure.
Approximately 5 weeks later, he had a second event at home. While playing with his brother, his left arm went numb, and within seconds, his left arm, left hand, and left leg were twitching. The episode lasted 1 minute, during which he remained conscious but was very tired following the event.

The perinatal, developmental, medical, and family histories were unremarkable. Upon neurologic exam, mental status, cranial nerves, motor and sensory exam, deep tendon reflexes, coordination, and gait were all normal. A routine electroencephalogram (EEG) showed right centroparietal spike and slow waves with no tangential dipole and no activation with drowsiness or sleep. Brain magnetic resonance imaging (MRI) was normal.

\section{Diagnosis and Treatment}

This child was diagnosed with epilepsy of unknown etiology, characterized by focal seizures. Although some of the features suggest a benign syndrome such as Benign Childhood Epilepsy with CentroTemporal Spikes, the lack of activation of epileptiform discharges during drowsiness and sleep make this diagnosis less likely.

AED therapy was recommended, and after reviewing a few options, including potential side effects and availability of different formulations, OXC was selected, with the drug titrated over 3 weeks to $30 \mathrm{mg} / \mathrm{kg}$ day, divided into two daily doses.

The patient continued to have typical seizures and OXC was increased to $45 \mathrm{mg} / \mathrm{kg} /$ day. Seizures continued to occur and a switch to LEV monotherapy was attempted without success. As the dose of OXC was reduced, seizures became more frequent. Eventually, OXC and LEV combination therapy improved seizure frequency by $50 \%$.

\section{Discussion}

The availability of a child-friendly formulation is an important consideration in the treatment of pediatric epilepsy, as many children are not able to swallow even moderately sized tablets. The AEDS selected in this case are available as an oral suspension (OXC), and as an oral solution (LEV). Other formulations suitable for most young children are chewable tablets, orally disintegrating tablets and sprinkle capsules. If possible, a child-friendly, XR formulation should be considered, in order to decrease the risk for doserelated side effects, especially the ones affecting the central nervous system (sedation, dizziness, uncoordination, etc.) and the gastrointestinal system (stomach discomfort, nausea, vomiting, etc.) The selection of a formulation that is easy to take (and give by caregivers) with the fewest daily doses possible, will likely increase adherence to the prescribed treatment. As it was recently reported, early adherence to treatment could be an important factor in improving seizure outcomes. ${ }^{84}$ When possible, monotherapy should be attempted. Yet, if the use of polytherapy is required to improve seizure control, the fewest number of combination drugs should be sought, as this will likely result in a lower risk for side effects. ${ }^{85}$

\section{Case 2. Sleep Terror, Diagnosis and Treatment in the Elderly Presentation}

While traveling through Peru, a male patient (61 years) woke up completely disoriented, which was initially attributed to sunstroke. While driving some weeks later, his arms then body suddenly started trembling, leaving him frightened and disoriented for several minutes. Similar events occurred 
over the next 3 months, several times per month. Consequently, he had sleep difficulties, experiencing sleep terrors and memory problems, which occurred up to three times per night.

The patient did not suffer from other diseases except arterial hypertension, and no family history of neurologic diseases. Upon neurologic examination, cerebral nerves, movement, sensory function, coordination, and reflexes were normal. However, the patient complained of increasing memory impairments and several episodes of amnesia occurring within the last year. He also provided audio tape recordings demonstrating night-time screaming lasting about 20 seconds.

Differential workup concerning non-epileptic sleep terror, psychogenic pseudo seizures, and epileptic seizures was performed. A long-term video EEG polygraphic recording, including electrocardiogram (ECG) and sleep polysomnography, was collected. During video-EEG-monitoring, interictal theta waves were recognized temporal right. During an attack, open eyes, distorted face, gestural hyperkinetic movements of all extremities, oral automatisms (smacking with lips), tachycardia, and goose bumps occurred. The EEG showed nonrapid eye movement (NREM 2) sleep and flattening as well as muscle artifacts. The attack duration was 18 seconds followed by a fast reorientation.

MRI showed normal findings in the gray and white matter. No marked decrease or increase of metabolism was noted via fludeoxyglucose-positron emission tomography (FDG-PET). An ictal single-photon emission computed tomography (SPECT) was performed and showed focal hyperperfusion in the right amygdala region. The magnetic resonance spectroscopy (MRS) investigation indicated a decrease of $\mathrm{N}$-acetyl aspartate (NAA) in the amygdala region right. The analysis of the cerebral spinal fluid was normal.

\section{Diagnosis and Treatment}

Considering all investigation results, mesial temporal lobe epilepsy of unknown origin was diagnosed.

Treatment was started with LEV. After slow titration up to 1,000 mg LEV, seizure frequency was reduced by $70 \%$. Due to skin allergy fears, LTG was not used, but a low dose of TPM up to $100 \mathrm{mg} / \mathrm{d}$ added; LEV in combination was reduced to 500 to $1,000 \mathrm{mg} / \mathrm{d}$. Under this combination therapy the patient reported further improvement.

\section{Discussion}

When selecting AEDs for elderly patients, drugs with missing or low interaction potential should be considered because most epilepsy patients are treated with other drugs. ${ }^{86}$ Comorbidities with cognitive, emotional, or sleep disturbances also influence AED selection. In this respect, LEV and LTG are well tolerated in terms of cognitive function. If irritation occurs, the dosage of LEV must be reduced. To avoid cognitive impairment, a low dose of TPM (50 to $100 \mathrm{mg}$ ) can be helpful. With adherence problems, once-daily dosage of AEDS may be easier controlled by nurses. In elderly patients, once-daily evening administration of VPA or once-daily morning administration of LTG (in order to avoid sleep difficulties) was used.

Due to slow titration rate and problems falling asleep, LTG was not used as first monotherapy. CBZ and OXC were avoided with regard to enzyme induction and risk for hyponatremia in the elderly.

\section{Case 3. Distinction Between Focal and Idiopathic Generalized Epilepsy Presentation}

A 36-year-old right-handed woman developed her first seizure 1 month before presentation to the epilepsy clinic. She felt odd, then lost consciousness, turned her head to the left, became stiff, and shook all over. She was taken to the emergency room where she had another episode. She turned her head to the left as if following something, stiffened, and had generalized jerking activity. Five days later, she had two more attacks, one of which was witnessed by her mother who noted versive head turning to the right before generalized jerking activity. She was already on PGB for fibromyalgia and she had increased her PGB dose just before the first seizure episode. Following her third seizure she was started on LEV, $750 \mathrm{mg}$ twice a day, and PGB was removed. There was no recurrence of seizures initially. EEG was normal in waking, drowsiness, and sleep, and MRI was normal. She was seizure free for 21 months, then seizures recurred, initially after missing 2 days of LEV, but then while taking it regularly. She had approximately one convulsive seizure every 4 to 6 months. She also developed smaller seizures, starting approximately 3 years after her first major seizure. These were precipitated by stress. She called them 'partial seizures' and described them as going into a dream state during which she could hear people talking but could not tell what they were saying. She estimated two to three occurrences per month. These seizures continued despite increasing the dose of LEV to 2,500 mg per day. Video-EEG in the Epilepsy Monitoring Unit recorded two generalized tonic-clonic seizures that started on EEG with generalized 4-5 Hz spike-and-wave discharges (see Figure 1). She also had a cluster of generalized absence seizures associated with generalized 3-4 Hz spike-and-wave discharges (see Figure 2). LTG was then added, titrated to $100 \mathrm{mg}$ bid, and LEV was reduced to $1,000 \mathrm{mg}$ bid due to some jitteriness. She had no recurrence of generalized tonic-clonic seizures; however, 6 months later she reported small episodes of losing her conversation for a few seconds. We increased LTG to 300 then $400 \mathrm{mg}$ per day. She has remained seizure free for at least 2 years.

\section{Diagnosis and Treatment}

The patient was diagnosed with idiopathic generalized epilepsy (IGE) with generalized absence and generalized tonic-clonic seizures. Versive head turning may have suggested focal onset, but is not unusual in primary generalized tonic-clonic seizures. ${ }^{87}$ What the patient called partial seizures probably represented generalized absence seizures. IGE usually starts before age 20 but may occasionally start later, up to $5.7 \%$ after age 30 in one study.8 ${ }^{88}$ The diagnosis of generalized epilepsy helped in choosing a medication appropriate for generalized epilepsy, and avoiding medications that are specific for focal epilepsy. ${ }^{89}$

\section{Discussion}

The distinction between focal epilepsy and IGE is important for the appropriate choice of AED therapy. In particular, some AEDS have the potential to precipitate or exacerbate some generalized seizure types such as myoclonic or absence seizures. This has been reported for CBZ, OXC, GBP, PGB, TGB, and VGB, all of which should be avoided in the treatment of IGE. The clinical distinction of focal and generalized seizures can be straightforward in some instances and challenging in others, requiring recording of seizures on EEG and video. 


\section{Figure 1: Generalized Electroencephalogram onset for the First Generalized Tonic- Clonic Seizure}

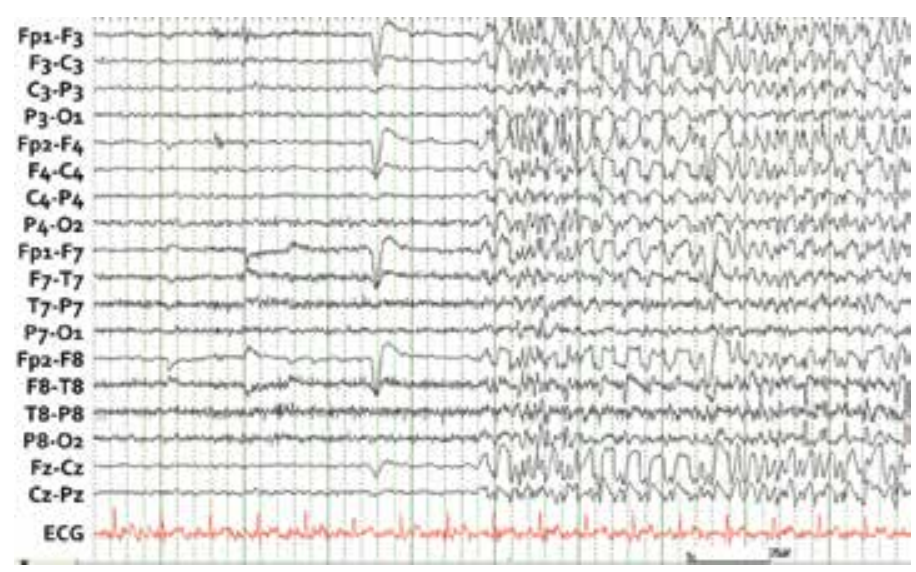

\section{Figure 2: Generalized $3 \mathrm{~Hz}$ Spike-and-wave Discharge Associated with a Generalized Absence Seizure}

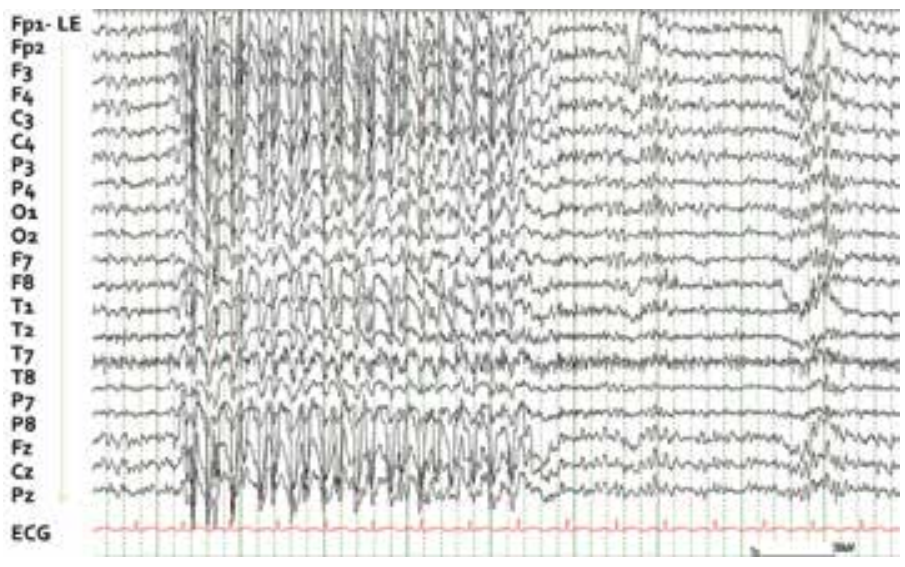

\section{Case 4. Limbic Simple Partial Seizures with Cardiovascular Masking Presentation}

A 39-year old man presented with a 16-year history of stereotypical episodes. He reported sudden onset of shortness of breath, with difficulty speaking, followed by bilateral eye 'fluttering' movements, with no change in consciousness during events. Duration was typically 10-15 seconds. At onset, symptoms occurred once or twice a year, but subsequently increased in frequency to daily, sometimes occurring five times per day, often awakening him from sleep.

Ten years after onset of symptoms, he underwent extensive cardiac workup including 24-hour Holter monitor, which resulted in pacemaker placement, which had no effect on his symptoms, and was subsequently deactivated 1 year after placement. Before presentation at age 39 , he was not treated with antiepileptic medications.

There was no history of febrile seizures or significant head trauma. The patient was the product of a normal pregnancy and delivery with normal developmental milestones.

\section{Diagnosis and Treatment}

Video EEG monitoring showed approximately 10 seizures per day, with associated signs of inattentiveness documented by inability to consistently follow simple commands, which often progressed to bilateral eyelid fluttering and mouthing movements. After the events, he was immediately conversant, and able to accurately recall his symptoms. With all events, there was a stereotypical associated bradycardia to $30-40$ beats per minute, which began approximately 5 to 6 seconds after symptom onset, lasting 5 seconds before resolving. There were no inter-ictal epileptiform discharges. There were associated ictal EEG changes, with some events showing diffuse, $7-8 \mathrm{~Hz}$ activity at the end of the event. Head CT was normal. MRI was contraindicated because of his pacemaker.

The patient started CBZ, titrating to a dose of $600 \mathrm{mg}$ twice daily, with complete resolution of symptoms. He has remained seizure free for years since initiation of CBZ.

\section{Discussion}

This case represents an atypical presentation of simple partial epileptic seizures of limbic origin. Clinical historical factors favoring the diagnosis of epilepsy include the similarity and duration of symptoms during repetitive events. While ictal EEG changes helped in confirming the epileptic etiology of symptoms, they did not localize the origin of seizures. Ictal signs and symptoms suggest origin in the limbic system, with associated difficulty breathing, mouthing automatisms, and bradycardia. The anterior cingulate gyrus, which regulates many autonomic motor functions, represents a possible region of seizure onset. Localization to the cingulate gyrus is also supported by the associated bilateral peri-orbital facial movements, because the M3 facial movement center projects bilaterally to the upper quadrant of the face, and is located in the anterior cingulate region. ${ }^{90}$ While typical semiology for anterior cingulate-onset seizures includes hypermotor activity, a subset of subjects with atypical anterior cingulate includes only simple motor seizures. Scalp EEG changes often are nonlocalizing, and ictal patterns can be widespread. ${ }^{91}$

Importantly, the case highlights the involvement of the cardiovascular system in seizures. The patient's diagnosis was delayed for many years because of the initial diagnostic focus on cardiovascular symptoms. Investigation of other associated symptoms eventually led to testing with video EEG monitoring, and confirmation of epileptic seizures. Given the lack of interictal EEG abnormalities, capturing the symptoms during video EEG monitoring was important for diagnosis. While diagnosis was delayed, his response to treatment was prompt. Like most patients with epileptic seizures, his seizures came under good control with antiepileptic medication treatment. 
1. Schmidt $D$, Gram L, Monotherapy versus polytherapy in epilepsy, CNS Drugs, 1995:3:194-208.

2. Deckers CL, Czuczwar SJ, Hekster YA, et al., Selection of antiepileptic drug polytherapy based on mechanisms of action: the evidence reviewed, Epilepsia, 2000;41:1364-74.

3. Kaminski RM, Matagne A, Patsalos PN, Klitgaard H, Benefit of combination therapy in epilepsy: a review of the preclinical evidence with levetiracetam, Epilepsia, 2009;50:387-97.

4. Kwan P, Schachter SC, Brodie MJ, Drug-resistant epilepsy, N Eng/ J Med, 2011;365:919-26.

5. Privitera $\mathrm{M}$, Current challenges in the management of epilepsy, Am J Manag Care, 2011;17(Suppl. 7):S195-203.

6. LaRoche SM, Helmers SL, The new antiepileptic drugs: clinical applications, JAMA, 2004;291:615-20.

7. Loscher W, Schmidt D, Modern antiepileptic drug development has failed to deliver: ways out of the current dilemma, Epilepsia, 2011:52:657-78

8. Faught $\mathrm{E}$, Antiepileptic drug trials: the view from the clinic, Epileptic Disord, 2012;14:114-23.

9. Mohanraj R, Brodie MJ, Measuring the efficacy of antiepileptic drugs, Seizure, 2003;12:413-43.

10. Kwan P, Brodie MJ. Combination therapy in epilepsy: when and what to use, Drugs, 2006;66:1817-29.

11. Brodie MJ, Sills GJ, Combining antiepileptic drugs-rational polytherapy?, Seizure, 2011;20:369-75

12. Brodie MJ, Yuen AW, Lamotrigine substitution study: evidence for synergism with sodium valproate?, 105 Study Group, Epilepsy Res, 1997;26:423-2.

13. Pisani F, Oteri G, Russo MF, et al., The efficacy of valproatelamotrigine comedication in refractory complex partial seizures: evidence for a pharmacodynamic interaction, Epilepsia, 1999;40:1141-6

14. Sake JK, Hebert D, Isojarvi J, et al., A pooled analysis of lacosamide clinical trial data grouped by mechanism of action of concomitant antiepileptic drugs, CNS Drugs, 2010:24:1055-68.

15. Poolos NP, Warner LN, Humphreys SZ, Williams $S$, Comparative efficacy of combination drug therapy in refractory epilepsy, Neurology, 2012;78:62-8.

16. Margolis JM, Chu BC, Wang ZJ, et al., Effectiveness of antiepileptic drug combination therapy for partial-onset seizures based on mechanisms of action, JAMA Neurol, 2014;71:985-93.

17. Aptiom ${ }^{\varpi}$, (eslicarbazepine) Prescribing Information: Sunovion Pharmaceuticals Inc. Marlborough, MA, US: 2013.

18. Ben-Menachem E, Gabbai AA, Hufnagel A, et al., Eslicarbazepine acetate as adjunctive therapy in adult patients with partial epilepsy, Epilepsy Res, 2010;8:278-85

19. Elger C, Halasz P, Maia J, et al., Efficacy and safety of eslicarbazepine acetate as adjunctive treatment in adults with refractory partial-onset seizures: a randomized, double-blind, placebo-controlled, parallel-group phase III study, Epilepsia, 2009;50:454-63.

20. Sperling M, Harvey J, Biraben A, et al., Adjunctive eslicarbazepine acetate in patients with refractory partial-onse seizures: efficacy results of a 12 week randomized placebocontrolled study. American Epilepsy Society Annual Meeting. Washington, DC. Abst. 3.210 (meeting abstracts online); 2013

21. Gabapentin as add-on therapy in refractory partial epilepsy: a double-blind, placebo-controlled, parallel-group study. The US Gabapentin Study Group No. 5, Neurology, 1993:43:2292-8.

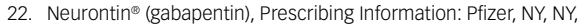
US; 2013.

23. Vimpat ${ }^{\oplus}$ (lacosamide), Prescribing Information: UCB Pharma Smyrna, GA, US; 2014

24. Ben-Menachem E, Biton V, Jatuzis $D$, et al., Efficacy and safety of oral lacosamide as adjunctive therapy in adults with partial-onset seizures, Epilepsia, 2007;48:1308-17.

25. Chung S, Sperling MR, Biton V, et al., Lacosamide as adjunctive therapy for partial-onset seizures: A randomized controlled trial, Epilepsia, 2010;51:958-67.

26. Halász P, Kälviäinen R, Mazurkiewicz-Beldzinska M, et al. Adjunctive lacosamide for partial-onset seizures: Efficacy and safety results from a randomized controlled trial, Epilepsia, 2009;50:443-53.

27. Lamictal ${ }^{\circledR}$ (lamotrigine), Prescribing Information: GlaxoSmithKline, Research Triangle Park, NC, US; 2013.

28. Matsuo F, Bergen D, Faught E, et al., Placebo-controlled study of the efficacy and safety of lamotrigine in patients with partial seizures. U.S. Lamotrigine Protocol 0.5 Clinical Trial Group, Neurology, 1993;43:2284-91.

29. Ben-Menachem E, Falter U, Efficacy and tolerability of levetiracetam $3000 \mathrm{mg} / \mathrm{d}$ in patients with refractory partial seizures: a multicenter, double-blind, responder-selected study evaluating monotherapy. European Levetiracetam Study Group Epilepsia, 2000;41:1276-83.

30. Cereghino JJ, Biton V, Abou-Khalil B, et al., Levetiracetam for partial seizures: results of a double-blind, randomized clinical trial, Neurology, 2000:55:236-42.

31. Trileptal ${ }^{\oplus}$ (oxcarbazepine), Prescribing Information: Novartis Pharmaceuticals Corporation, East Hanover, NJ, US; 2013.

32. Barcs G, Walker EB, Elger CE, et al., Oxcarbazepine placebocontrolled, dose-ranging trial in refractory partial epilepsy, Epilepsia, 2000;41:1597-607.

33. Steinhoff BJ, Ben-Menachem E, Ryvlin P, et al., Efficacy and safety of adjunctive perampanel for the treatment of refractory partial seizures: a pooled analysis of three phase III studies, Epilepsia, 2013;54:1481-9.

34. Fycompa ${ }^{\oplus}$ (perampanel), Prescribing Information: Eisai Inc Woodcliff Lake, NJ, US: 2012

35. Lyrica (pregabalin), Prescribing Information: Pfizer, NY, NY, US 2013.

36. Arroyo $S$, Anhut $H$, Kugler AR, et al. Pregabalin add-on treatment: a randomized, double-blind, placebo-controlled, dose-response study in adults with partial seizures, Epilepsia, 2004;45:20-7.

37. Beydoun A, Uthman BM, Kugler AR, et al., Safety and efficacy of two pregabalin regimens for add-on treatment of partial epilepsy, Neurology, 2005;64:475-80.

38. French JA, Kugler AR, Robbins JL, et al., Dose-response trial of pregabalin adjunctive therapy in patients with partial seizures, Neurology, 2003;60:1631-7.

39. Gabitri|凶 (tiagabine hydrochloride), Prescribing Information: Cephalon, Inc. Frazer, PA, US; 2010

40. Topamax ${ }^{\oplus}$ (topiramate), Prescribing Information: Janssen Pharmaceuticals, Inc., Titusville, NJ, US; 2009.

41. Sharief M, Viteri C, Ben-Menachem E, et al., Double-blind, placebo-controlled study of topiramate in patients with refractory partial epilepsy, Epilepsy Res, 1996;25:217-24.

42. Zonegran ${ }^{\oplus}$ (zonisamide), Prescribing Information: Eisai, Inc Woodcliff Lake, NJ, US; 2013

43. Faught E, Ayala R, Montouris GG, Leppik IE, Randomized controlled trial of zonisamide for the treatment of refractory partial-onset seizures, Neurology, 2001:57:1774-9.

44. Sabri ${ }^{\infty}$, (vigabatrin) Prescribing Information: Lundbeck, Deerfield IL, US; 2013

45. Potiga ${ }^{\circledast}$, (ezogabine) Prescribing Information: GlaxoSmithKline, Research Triangle Park, NC, US; 2013.

46. US Department of Health and Human Services UFaDA. FDA Drug Safety Communication: Anti-seizure drug Potiga (ezogabine) linked to retinal abnormalities and blue skin discoloration. http://www.fda.gov/drugs/drugsafety/ucm349538.htm. (accessed April 3, 2014).

47. Costa J, Fareleira F, Ascencao R, et al., Clinical comparability of the new antiepileptic drugs in refractory partial epilepsy: a systematic review and meta-analysis, Epilepsia, 2011;52:1280-91.

48. Gao L, Xia L, Zhao FL, Li SC, Clinical efficacy and safety of the newer antiepileptic drugs as adjunctive treatment in adults with refractory partial-onset epilepsy: a meta-analysis of randomized placebo-controlled trials, Epilepsy Res, 2013;103:31-44.

49. Rheims S, Perucca E, Cucherat M, Ryvlin P, Factors determining response to antiepileptic drugs in randomized controlled trials. A systematic review and meta-analysis, Epilepsia, 2011;:52:219-33.

50. Gazzola A, Seizure-free outcome in randomized add-on trials of the new antiepileptic drugs, Epilepsia, 2007;48:1303-7.

51. Beyenburg S, Stavem K, Schmidt D, Placebo-corrected efficacy of modern nonenzyme-inducing AEDs for refractory focal epilepsy: systematic review and meta-analysis, Epilepsia, 2012;53:512-20

52. Keppra ${ }^{\oplus}$ (levetiracetam), Prescribing Information: UCB Pharma, Smyrna, GA, US; 2011

53. US Department of Health and Human Services UFaDA. Drug Alerts and Statements. http://www.fda.gov/drugs/drugsafety/ ucm349538.htm (accessed October 9, 2013).

54. French JA, Gidal BE, Antiepileptic drug interactions, Epilepsia 2000;41(Suppl. 8):S30-6.

55. Ramsay RE, Rowan AJ, Pryor FM, Special considerations in treating the elderly patient with epilepsy, Neurology, 2004;62(5 Suppl. 2):S24-9.

56. Brodie MJ, Mintzer S, Pack AM, et al., Enzyme induction with antiepileptic drugs: cause for concern?, Epilepsia, 2013;54:11-27.

57. Mintzer S, Mattson RT, Should enzyme-inducing antiepileptic drugs be considered first-line agents? Epilepsia, 2009:50 (Suppl. 8):42-50.

58. Wilby J, Kainth A, Hawkins N, et al., Clinical effectiveness, tolerability and cost-effectiveness of newer drugs for epilepsy in adults: a systematic review and economic evaluation, Health Technol Assess, 2005;9:1-157, iii-iv.

59. Meador KJ, Baker GA, Browning N, et al. Cognitive function at 3 years of age after fetal exposure to antiepileptic drugs, N Eng/ 」 Med, 2009;360:1597-605
60. Wlodarczyk BJ, Palacios AM, George TM, Finnell RH, Antiepileptic drugs and pregnancy outcomes, Am J Med Genet $A$ 2012:158A:2071-90

61. Hernandez-Diaz S, Smith CR, Shen A, et al., Comparative safety of antiepileptic drugs during pregnancy, Neurology, 2012;78:1692-99.

62. Arif $\mathrm{H}$, Buchsbaum R, Pierro J, et al., Comparative effectiveness of 10 antiepileptic drugs in older adults with epilepsy, Arch Neurol, 2010;67:408-15.

63. Zaccara G, Messori A, Cincotta M, Burchini G, Comparison of the efficacy and tolerability of new antiepileptic drugs: what can we learn from long-term studies?, Acta Neurol Scand, 2006;114:157-68

64. Simister RJ, Sander JW, Koepp MJ, Long-term retention rates of new antiepileptic drugs in adults with chronic epilepsy and learning disability, Epilepsy Behav, 2007;10:336-9.

65. Chung S, Wang N, Hank N, Comparative retention rates and long-term tolerability of new antiepileptic drugs, seizure 2007:16:296-304.

66. Peltola J, Peltola M, Auvinen A, et al., Retention rates of new antiepileptic drugs in localization-related epilepsy: a singlecenter study, Acta Neurol Scand, 2009;119:55-60.

67. Stefan $\mathrm{H}$, Improving the Effectiveness of Drugs in Epilepsy Through Concordance, ACNR: Advances in Clinical Neuroscience Rehabilitation, 2009;8(6):15-8.

68. Davis KL, Candrilli SD, Edin HM, Prevalence and cost of nonadherence with antiepileptic drugs in an adult managed care population, Epilepsia, 2008:49:446-54.

69. Faught $\mathrm{E}$, Duh MS, Weiner JR, et al., Nonadherence to antiepileptic drugs and increased mortality: findings from the RANSOM Study, Neurology, 2008;71:1572-8.

70. Hovinga CA, Asato MR, Manjunath R, et al., Association of nonadherence to antiepileptic drugs and seizures, quality of life, and productivity: Survey of patients with epilepsy and physicians, Epilepsy Behav, 2008:13:316-22.

71. Claxton AJ, Cramer J, Pierce C, A systematic review of the associations between dose regimens and medication compliance, Clin Ther, 2001;23:1296-310.

72. Pellock JM, Smith MC, Cloyd JC, et al., Extended-release formulations: simplifying strategies in the management of antiepileptic drug therapy, Epilepsy Behav, 2004;5:301-7.

73. Bialer M, Extended-release formulations for the treatment of epilepsy, CNS Drugs, 2007;21:765-74.

74. Lamictal $X R \otimes$ (lamotrigine), Prescribing Information: GlaxoSmithKline, Research Triangle Park, NC, US; 2011

75. Keppra XR® (levetiracetam), Prescribing Information: UCB Inc Smyrna, GA, US; 2014.

76. Oxtellar $\mathrm{XR}^{\mathrm{TM}}$ (oxcarbazepine), Prescribing Information: Supernus Pharmaceuticals Inc., Rockville, MD, US; 2012.

77. Qudexy ${ }^{T M} X R$ (topiramate), Prescribing Information: UpsherSmith Laboratories Inc., Maple Grove, MN, US; 2014.

78. Trokendi XRTM (topiramate), Prescribing Information: Supernus Pharmaceuticals Inc., Rockville, MD, US; 2013.

79. Adams C, Young A, Risky Rx: A Knight Ridder Investigation, Knight Ridder, Nov 2-4, 2003.

80. GoodRX. Www.goodrx.com. Accessed June 18, 2014

81. Liow K, Barkley GL, Pollard JR, et al., Position statement on the coverage of anticonvulsant drugs for the treatment of epilepsy, Neurology, 2007:68:1249-50.

82. Gidal $\mathrm{BE}$, Generic antiepileptic drugs: how good is close enough? Epilepsy Curr, 2012;12:32-4.

83. Privitera $\mathrm{M}$, Generic substitution of antiepileptic drugs: What's a clinician to do? Neurol Clin Pract, 2013;3:161-4.

84. Modi AC, Rausch JR, Glauser TA, Early pediatric antiepileptic drug nonadherence is related to lower long-term seizure freedom, Neurology, 2014;82:671-3.

85. Morita DA, Glauser TA, Modi AC, Development and validation of the Pediatric Epilepsy Side Effects Questionnaire, Neurology, 2012;79:1252-8.

86. Stefan $\mathrm{H}$, Epilepsy in the elderly: facts and challenges, Acta Neurol Scand, 2011;124:223-37.

87. Chin PS, Miller JW, Ictal head version in generalized epilepsy, Neurology, 2004;63:370-2.

88. Reichsoellner J, Larch J, Unterberger I, et al., Idiopathic generalised epilepsy of late onset: a separate nosological entity? J Neurol Neurosurg Psychiatry, 2010;81:1218-22.

89. Benbadis SR, Tatum WO, Gieron M, Idiopathic generalized epilepsy and choice of antiepileptic drugs, Neurology, 2003;61:1793-5

90. Morecraft RJ, Stilwell-Morecraft KS, Rossing WR, The motor cortex and facial expression: new insights from neuroscience Neurologist, 2004;10:235-49.

91. Alkawadri R, So NK, Van Ness PC, Alexopoulos AV, Cingulate epilepsy: report of 3 electroclinical subtypes with surgical outcomes, JAMA Neurol, 2013;70:995-1002. 